\title{
Amended description and conservation status of Stigmaphyllon carautae (Malpighiaceae)
}

\author{
Rafael Felipe de Almeida ${ }^{1,2}$
}

\begin{abstract}
I present new data on the Atlantic Forest endemic Stigmaphyllon carautae (Malpighiaceae), including an amended morphological description describing fruits and seeds for the first time. Additionally, I present the first analysis of its conservation status.

Key words: Brazil, Espírito Santo state, Malpighiales, Stigmaphylloid, taxonomy.

\section{Resumo}

Apresento novos dados sobre o Stigmaphyllon carautae (Malpighiaceae), endêmico da Floresta Atlântica, incluindo uma descrição morfológica emendada descrevendo seus frutos e sementes pela primeira vez. Adicionalmente, apresento a primeira análise de seu status de conservação.

Palavras-chave: Brasil, Espírito Santo, Malpighiales, Stigmaphylloide, taxonomia.
\end{abstract}

\section{Introduction}

Stigmaphyllon A. Juss. comprises ca. 120 species occurring within the Neotropics, Pacific Islands, Southeast Asia, West Africa, and Western Australia (Almeida \& Amorim 2014; Anderson 2011). Most species are woody vines with longpetiolate, elliptical to cordate leaves, clusters of yellow flowers arranged in dichasia, styles with lateral foliar appendages at the apex, and schizocarps splitting into three mericarps, each usually bearing a large dorsal wing (Anderson 1997, 2011). About $75 \%$ of its species are confined to the Neotropics, being especially diverse along water streams in the Amazon and Atlantic Forests (Anderson 1997; Almeida \& Amorim 2014).

In Brazil, the genus is especially diverse in the Atlantic with 31 from ca. 45 species occurring almost exclusively in this biome (BFG 2015). Field trips in poorly collected areas in the Atlantic Forest of Espírito Santo and Minas Gerais states, have contributed to the understanding of enigmatic species in Malpighiaceae (Almeida 2015; Almeida \& Amorim 2015; Almeida \& Pellegrini 2016; Almeida et al. 2015; Amorim \&
São-Matheus 2008; Sebastiani \& Mamede 2010). Recent field collections from Southern Espírito Santo state rediscovered an endangered species of Stigmaphyllon previously endemic to the state of Rio de Janeiro.

We present an amended description of Stigmaphyllon carautae C.E. Anderson, including the description for the first time of fruit and seed morphology.

\section{Methods}

Morphological and phenological data were based on field and herbaria samples (CEPEC, GUA, HUEFS, MICH, R, RB; herbaria acronyms according to Thiers, continuously updated). The indumentum terminology follows Anderson (1981), structure shapes follows Radford et al. (1974), the inflorescence terminology and morphology follows Weberling $(1965,1989)$, and fruit terminology follows Spjut (1994) and Anderson (1981). The conservation status was proposed following the recommendations of IUCN Red List Categories and Criteria, Version 3.1 (IUCN 2012). GeoCAT (Bachman et al. 2011) was used for calculating

\footnotetext{
'Universidade Estadual de Feira de Santana, Depto. Ciências Biológicas, Prog. Pós-graduação em Botânica, Av. Transnordestina s/n, 44036-900, Feira de Santana, BA, Brazil.

${ }^{2}$ Author for correspondence: dealmeida.rafaelfelipe@gmail.com
} 
the Extent of Occurrence (EOO) and the Area of Occurrence (AOO). Maps were elaborated using QGIS 2.16 (QGIS Development Team 2015) and geographical coordinates were obtained from herbaria specimens and fieldwork data.

\section{Results and Discussion}

Stigmaphyllon carautae C.E. Anderson, Syst. Bot. Monogr. 51: 82. 1997. TYPE: BRAZIL. Rio de Janeiro: Bom Jesus de Itabapoana, Fazenda Dr. Colombino, dentro da floresta, 8 June 1982, fl., P. Carauta 4309 (holotype: GUA!; isotype: MICH!, R!). Figs. 1-3

Woody vines; stems costate, sparsely sericeous to glabrate at age; branches sericeous to glabrate at age. Stipules $0.8-1.1 \times 0.5-0.7 \mathrm{~mm}$ wide, free, triangular, eglandular, glabrous, occasionally deciduous. Leaves opposite, reduced in inflorescences; petioles 4-7 $\mathrm{cm}$ long, sparsely sericeous with scalelike T-shaped hairs, not confluent across the node, 2-glandular at apex, each gland 1.5-2 mm diam., cupulate; leaf blades 9-13 × 6.5-13 cm, pinnately 5-7-lobed (3-lobed to entire when associated to inflorescences), each lobe with a filiform hair at apex (broken off in herbarium specimens), base auriculate, adaxially glabrate, abaxially tomentose to sparsely tomentose (T-shaped hairs with trabecula 0.4-1 mm long, straight or wavy, stalk up to $0.1 \mathrm{~mm}$ long), hairs deciduous at age, margin shallowly and irregularly dentate, each tooth ending in a filiform hair (up to $5 \mathrm{~mm}$ long) or sometimes a stalked capitate gland $(0.2-0.3 \mathrm{~mm}$ in diameter, ca. $0.2-0.5 \mathrm{~mm}$ long) or sometimes the margin also with sessile glands (ca. $0.4 \mathrm{~mm}$ in diameter) (fringed with filiform hairs in leaves associated to inflorescences). Umbels, 15-20-flowered, disposed in dichasia; rachis with scalelike T-shaped hairs; peduncles 7-13 mm long, densely tomentose with scalelike T-shaped hairs; bracts 1.8-2.2 × 1.4-2 mm, triangular, apex acute, abaxially sericeous with scalelike T-shaped hairs, eglandular; bracteoles 2.5-3× 1.6-2.2 mm, oblong, apex obtuse, abaxially sericeous with scalelike T-shaped, eglandular. Flowers $1.5-1.7 \times 2-2.5$ $\mathrm{cm}$ diam; floral bud 6-8 $\mathrm{cm}$ diam., with a reddish macula; pedicels $6.5-11 \mathrm{~mm}$ long, tomentose with scalelike T-shaped hairs. Sepals 3.5-4 × 2-3 mm, glands 1.8-2.1 × 1-1.2 mm, green to yellowish. Petals yellow, glabrous, margin lacerate-fimbriate, fimbriae 0.9-1.1 mm long; lateral petals with limb 15-17 $\times 15-17 \mathrm{~mm}$, obovate to orbicular, claw 2-3 mm long; posterior petal with limb 14-15.5 $\times$ 14-15.5 mm, obovate, with reddish stripes at base, claw 3.8-4 mm long, apex dented. Androecium with 10 stamens; filaments $1.5-3.5 \mathrm{~mm}$ long, unequal, those opposite the posterior styles the largest, those opposite the anterior-lateral sepals with the connective enlarged and the locules reduced; anthers 0.7-1.6 mm long, glabrous. Ovary 1.3-1.5 $\times 1.3-1.5 \mathrm{~mm}$, tomentose; styles 3.1-3.4 mm long, anterior style slightly shorter than the posterior ones, erect (posterior styles lyrate); laterally compressed, tomentose at base, apex 0.8-0.9 mm long, distally blunt, folioles absent. Samaras 3, dorsal wing 3-3.5 $\times 1.2-1.5 \mathrm{~cm}$, reddish, densely sericeous (T-shaped hairs with trabecula $0.4-1 \mathrm{~mm}$ long, straight or wavy, stalk up to $0.1 \mathrm{~mm}$ long), hairs deciduous at age; nut 10-12 × 6-7 mm, prominent, smooth or with two lateral ridges, densely sericeous (T-shaped hairs with trabecula $0.4-1 \mathrm{~mm}$ long, straight or wavy, stalk up to $0.1 \mathrm{~mm}$ long), hairs deciduous at age; areole 6-7 $\times$ 4-5 mm, wide-oblong, rugose. Seeds (immature) 3-5 × 1.5-2 mm, oblong, rugose; embryo 3.4-4.7 $\times$ 1.7-1.9 mm, outer cotyledon folded over the inner cotyledon.

Specimens examined: BRAZIL. Espírito Santo: Cachoeiro do Itapemirim, distrito de Burarama, Pedra do Cantagalo, 2041'22''S, 41²2'24'W, 20.V.2016, fl. e fr., R.G.Barbosa-Silva et al. 509 (RB).

Distribution, habitat and phenology: Stigmaphyllon carautae is known only from Seasonally Dry Forests associated to inselbergs from northern Rio de Janeiro and southern Espírito Santo states (Fig. 2). It grows in clearings and edges of secondary forests. Flowering from May to June and fruiting in May.

Conservation status: Stigmaphyllon carautae is represented by only two records restricted to highly fragmented areas of Seasonally Dry in the borders of Espírito Santo and Rio de Janeiro states. Its AOO comprises $8.000 \mathrm{~km}^{2}$ within Semideciduous Dry Forests highly fragmented, due to several threats imposed by farming, logging and mining activities (Almeida \& Mamede 2014). Combined with its extent of occurrence, $S$. carautae can be regarded as a critically endangered species (criteria B1a and B1b).

Comments: Stigmaphyllon carautae is one of the seven species ( $S$. auriculatum (Cav.) A.Juss., $S$. ciliatum (Lam.) A.Juss., S. jatrophifolium A.Juss., S. macedoanum C.E.Anderson, S. mikanifolium R.F.Almeida \& Amorim, and S. vitifolium A.Juss.) of this genus from the Atlantic Forest to bear ciliate/ filiform hairs on the margins of leaf blades (Fig. 3) (Anderson 1997). Those hairs have previously thought to be filiform glands in some species, but recent studies on its micromorphology shed light into its true nature as hairs (Almeida \& Mamede 

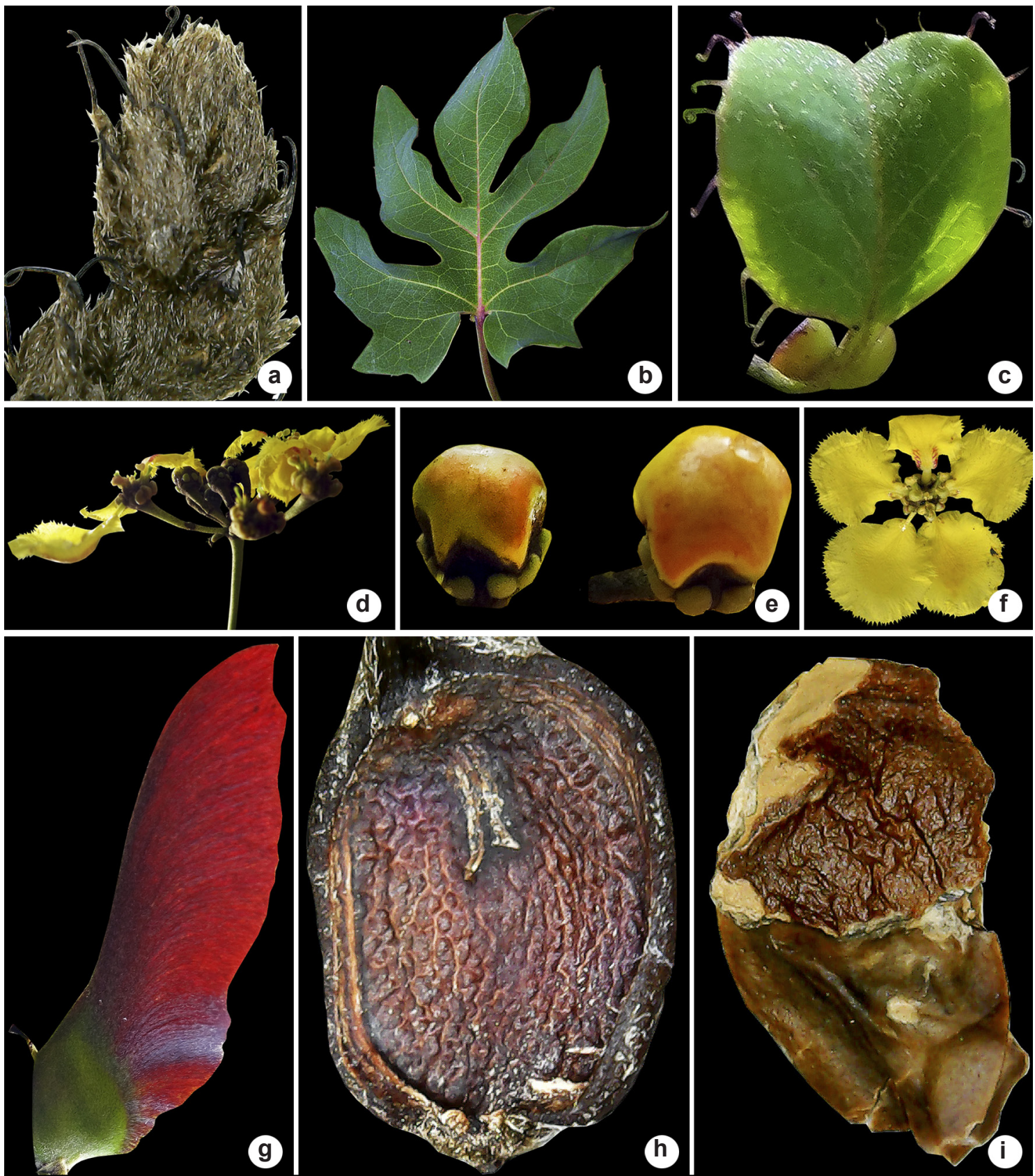

Figure 1 - Stigmaphyllon carautae - a. leaf shoot; b. adaxial side of a leaf; c. detail of sericeous young leaves bearing filiform hairs; d. flowering branch; e. floral bud; f. flower in frontal view; g. samaras in lateral view; h. areole of a samara in frontal view; i. immature seed in lateral view. Photos: R.G.B. Silva.

2016). On leaf shoots of S. carautae, it is possible to observe long filiform hairs involving young leaves (Fig. 1a). Since those hairs seem to fall or break along leaf expansion, we hypothesize that they might protect leaf shoots from herbivory of its delicate membranous leaves. All Stigmaphyllon species from the Atlantic Forest bearing ciliate/filiform hairs show delicate and membranous leaf blades. In addition, those species inhabit dry and poor-nutrient phytophysiognomies such as caatingas, restingas, or rocky outcrops along the Atlantic coast. A key to the abovementioned species are presented: 


\section{Key to the Stigmaphyllon species with ciliate/filiform hairs in the Atlantic Forest}

1. Stigmas of posterior styles facing the posterior petal

1'. Stigmas of posterior styles facing each other or the anterior style .................................................. 3

2. Leaf blades sparsely ciliate with short filiform hairs when mature (Fig. 3b); posterior petal with reddish stripes (Fig. 4b); samaras with dorsal wing elongated (Fig. 5b), nut smooth (Fig. 5b) .....

Stigmaphyllon carautae

2'. Leaf blades densely ciliate with long filiform hairs when mature (Fig. 3e,f); posterior petal yellow (Fig. 4a); samaras with dorsal wing reduced (Fig. 5c), nut rugose (Fig. 5c)

Stigmaphyllon ciliatum

3. Stems with internodes forming a corky ridge (Fig. 4e); stigmas of posterior styles facing the anterior style (Fig. 4e)

Stigmaphyllon macedoanum

3'. Stems with internodes smooth; stigmas of posterior styles facing each other...................... 4

4. Pedicels glabrous to glabrate; posterior petal yellow ................................................... 5

4'. Pedicels pubescent; posterior petal reddish................................................................. 6

5. Leaf blades ovate (Fig. 3a), hastate or 2-3-lobed, margin entire (Fig. 3a); posterior petal larger than $10 \mathrm{~mm}$ diam. (Fig. 4a); samaras with nut smooth (Fig. 5a)

Stigmaphyllon auriculatum

5'. Leaf blades 5-7 lobed (Fig. 3c), margin dentate (Fig. 3c); posterior petal up to 9 mm diam. (Fig. 4d); samaras with nut bearing a lateral crest (Fig. 5d) ....

Stigmaphyllon jatrophifolium

6. Leaf blades 5-7-lobed (Fig. 3d), margin dentate (Fig. 3d); petioles with a pair of glands bellow apex (Fig. 3d); petals with dentate to erose margins (Fig. 4g)

Stigmaphyllon vitifolium

6'. Leaf blades reniform (Fig. 3h), margin lobulate (Fig. 3h); petioles with a pair of glands at apex (Fig. 3h); petals with fimbriate margins (Fig. 4f).

Stigmaphyllon mikanifolium



Figure 2 - Distribution map of Stigmaphyllon carautae in Southeastern Brazil. 

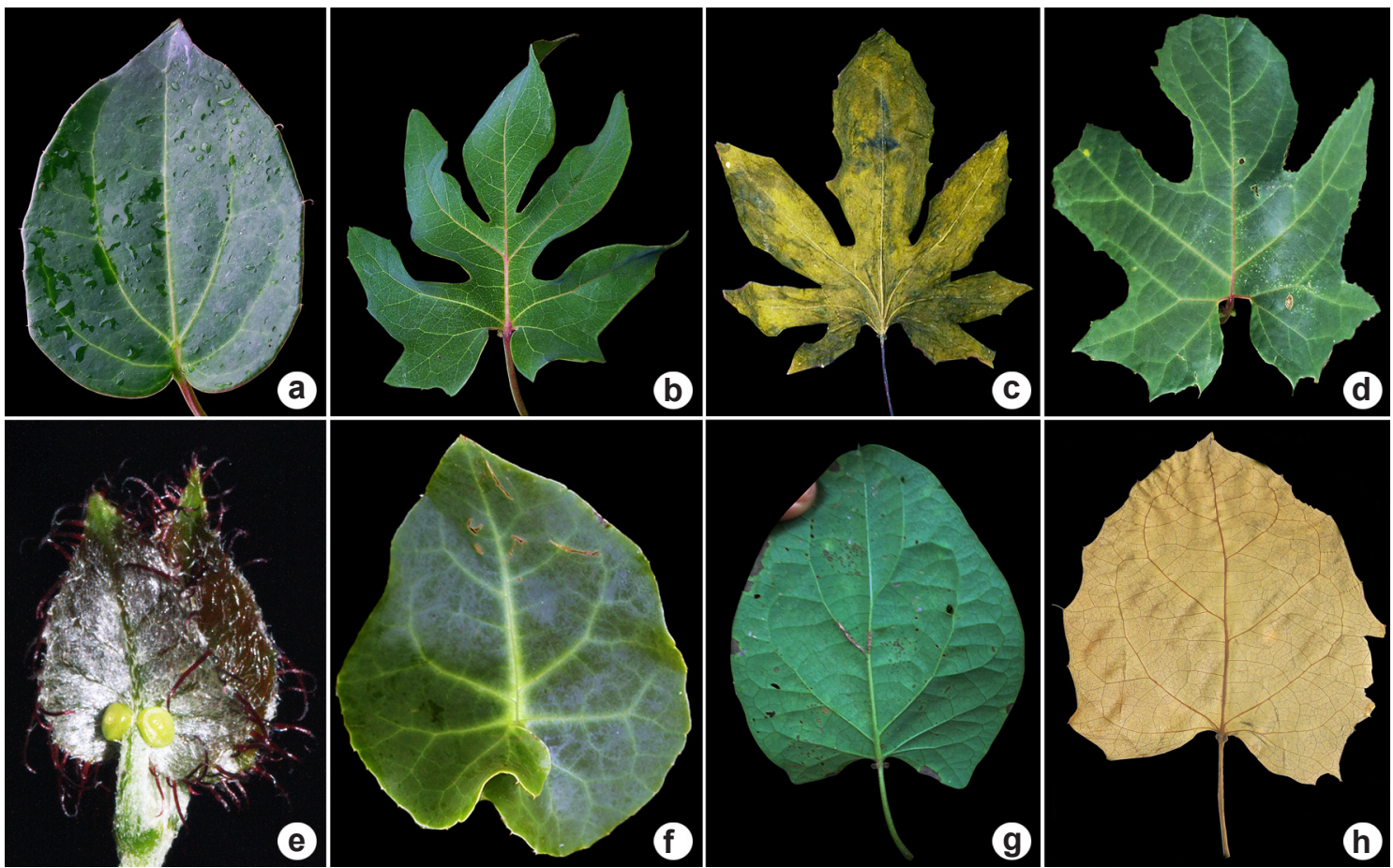

Figure 3 - Leaves of Stigmaphyllon species from the Atlantic Forest bearing ciliate/filiform hairs (white arrows) - a. S. auriculatum; b. S. carautae; c. S. jatrophifolium; d. S. vitifolium; e. young leaves of S. ciliatum; f. mature leaf of S. ciliatum; g. S. macedoanum; h. S. mikanifolium. Photos: a,c,h. R.F.Almeida; b. R.G.B.Silva; d. A.C.S.DalCol; e,f. M.O.O.Pellegrini; g. R.Arruda.
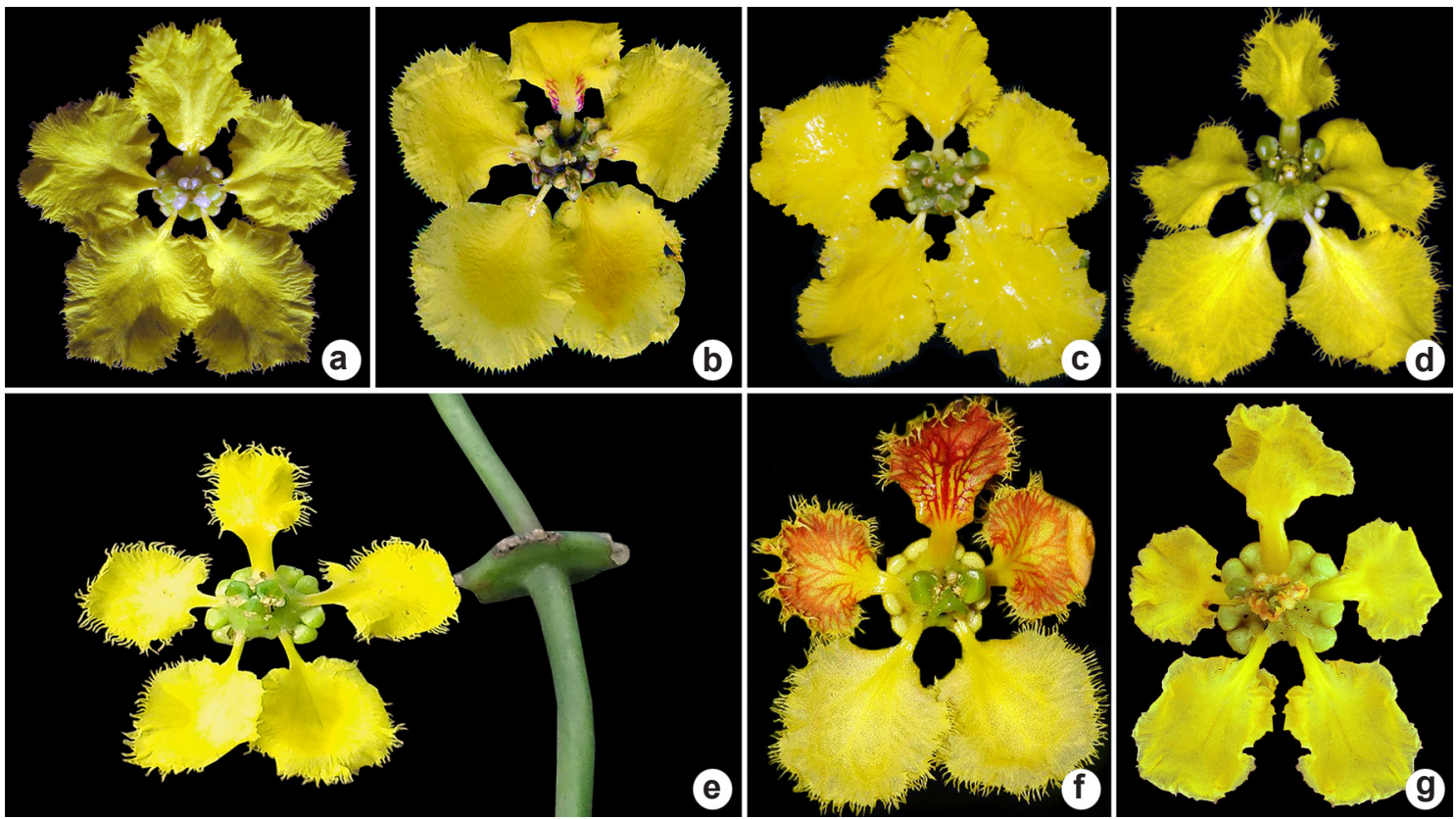

Figure 4 - Flowers of Stigmaphyllon species from the Atlantic Forest bearing ciliate/filiform hairs - a. S. auriculatum; b. S. carautae; c. S. ciliatum; d. S. jatrophifolium; e. S. macedoanum; f. S. mikanifolium; g. S. vitifolium. Photos: a. R.F.Almeida; b. R.G.B.Silva; c. M.O.O.Pellegrini; d. W.R.Anderson; e. R.Arruda; f. C.N.Fraga; g. A.C.S.DalCol. 

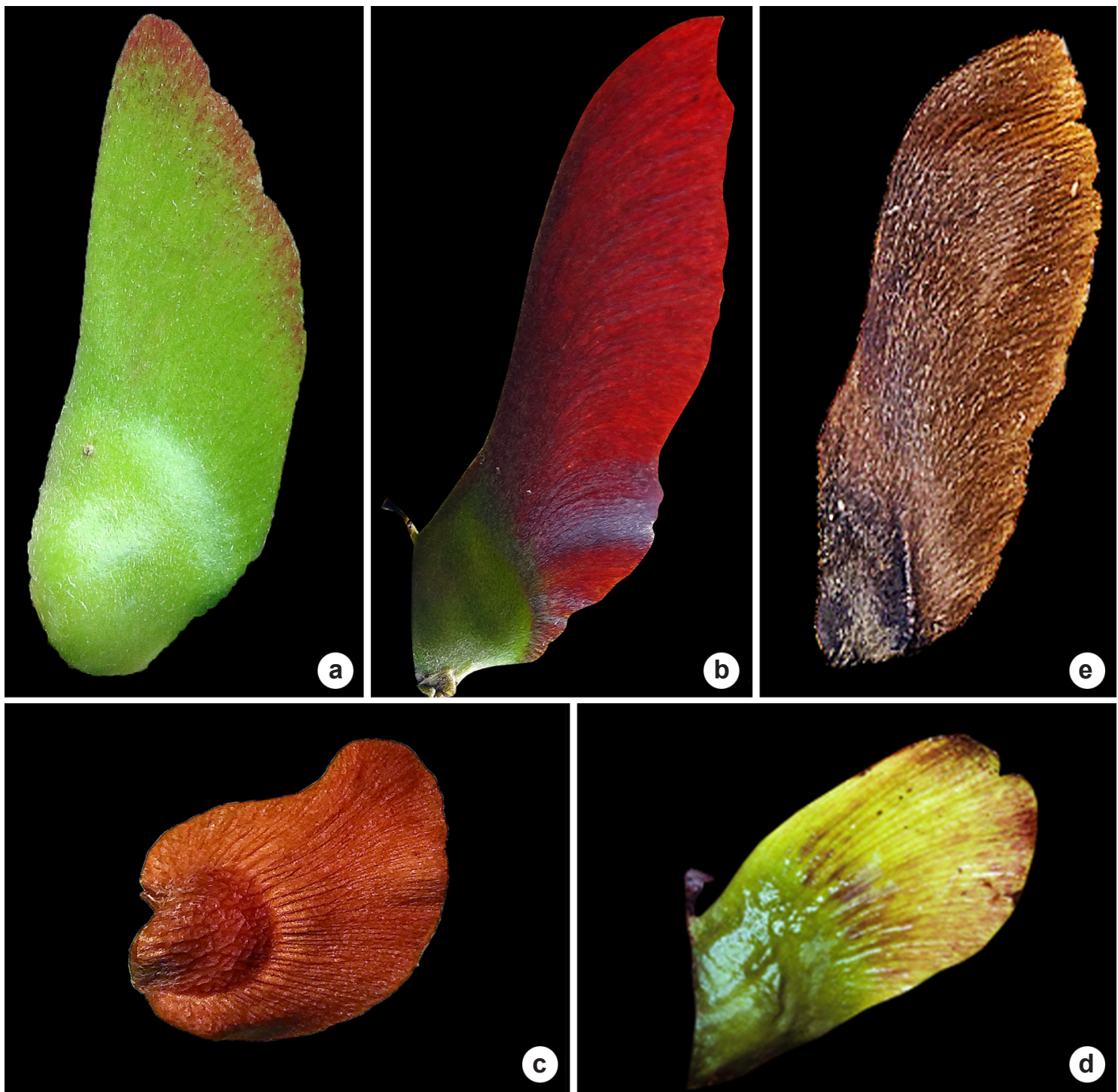

Figure 5 - Fruits of Stigmaphyllon species from the Atlantic Forest bearing ciliate/filiform hairs - a. S. auriculatum; b. S. carautae; c. S. ciliatum; d. S. jatrophifolium; e. S. vitifolium. Photos: a. C.Pessoa; b. R.G.B.Silva; c,e. R.F.Almeida; d. W.R.Anderson.

\section{Acknowledgements}

I would like to thank Marco Octávio de Oliveira Pellegrini and Rafael Gomes BarbosaSilva for valuable comments on an early version of the manuscript; A.C.S. Dal Col, C.N. Fraga, C. Pessoa, M.O.O. Pellegrini, R. Arruda, R.G. Barbosa-Silva, and W.R. Anderson for field photographs; FAPESB for my Ph.D. fellowship (DEB BOL0584/2013); and Universal Malpighiales (DEB 486079/2013-9), and Reflora Malpighiales (DEB 563548/2010-0) for sponsoring my herbarium studies.

\section{References}

Almeida RF \& Amorim AM (2014) Stigmaphyllon caatingicola (Malpighiaceae), a new species from Seasonally Dry Tropical Forests in Brazil. Phytotaxa 174: 82-88.

Almeida RF (2015) New records of Stigmaphyllon puberulum Griseb. (Malpighiaceae) from the Atlantic Forest, northeastern Brazil. Check List 11: 1510-1512.

Almeida RF \& Amorim AM (2015) Stigmaphyllon mikanifolium (Malpighiaceae), a new species from Espírito Santo state, Brazil. Kew Bulletin 70: 47. 
Almeida RF \& Pellegrini MOO (2016) Synopsis of Bunchosia Kunth (Malpighiaceae) from the Atlantic Forest. Phytotaxa 257: 158-166.

Almeida RF \& Mamede MCH (2016) Sinopse de Malpighiaceae no estado do Espírito Santo, Brasil: Stigmaphyllon A.Juss. Hoehnea 43: 601-633.

Amorim AM \& São-Matheus WMB (2009) Redescrição de Heteropterys bahiensis Nied. (Malpighiaceae). Rodriguésia 60: 367-370.

Anderson CE (1997) Monograph of Stigmaphyllon (Malpighiaceae). Systematic Botany Monographs 51: $1-313$.

Anderson CE (2011) Revision of Ryssopterys and transfer to Stigmaphyllon (Malpighiaceae). Blumea 56: 73-104.

Anderson WR (1981) Malpighiaceae. In: The botany of the Guayana Highland - Part XI. Memoirs of the New York Botanical Garden 32: 21-305.

Bachman S, Moat J, Hill AW, Torre J \& Scott B (2011) Supporting Red List threat assessments with GeoCAT: geospatial conservation assessment tool. e-Infrastructures for data publishing in biodiversity science. ZooKeys 150: 117-126.

BFG - The Brazil Flora Group (2015) Growing knowledge: an overview of seed plant diversity in Brazil. Rodriguésia 66: 1085-1113.

IUCN (2012) IUCN Red List categories and criteria: version 3.1. $2^{\text {nd }}$ ed. Gland, Switzerland and
Cambridge, UK: IUCN. Available at $<$ http://www. iucnredlist.org/technical-documents/categoriesand-criteria>. Access on 7 May 2016.

QGIS Development Team (2015) QGIS geographic information system. Open Source Geospatial Foundation Project. Available at $<\mathrm{http}$ ://qgis.osgeo. org >. Access on 7 May 2016.

Radford AE, Dickison WC, Massey JR \& Bell CR (1974) Vascular plant systematics. Harper \& Row, New York. Pp. 891.

Sebastiani R \& Mamede MCH (2010) Estudos taxonômicos em Heteropterys subsect. Stenophyllarion (Malpighiaceae). Hoehnea 37: 337-366.

Spjut RW (1994) A systematic treatment of fruit types. Memoirs of the New York Botanical Garden. Vol. 70. The New York Botanical Garden, New York. Pp. 1-181.

Thiers B [continuously updated] Index Herbariorum: a global directory of public herbaria and associated staff. New York Botanical Garden's Virtual Herbarium. Available at $<$ http://sweetgum.nybg. org/ih/>. Access on 7 May 2016.

Weberling F (1965) Typology of inflorescences. Botanical Journal of the Linnean Society 59: 15-221.

Weberling F (1989) Morphology of flowers and inflorescences. Cambridge University, Cambridge. Pp. 348. 